\title{
Performance Benchmarking of Active-Front-End Rectifier Topologies Used in High-Power, High-Voltage Onboard EV Chargers
}

\author{
Mehmet Uğraş CUMA *1 ORCID 0000-0001-6040-0362 \\ Murat Mustafa SAVRUN ${ }^{2}$ ORCID 0000-0001-5847-5082 \\ ${ }^{1}$ Çukurova University, Department of Electrical and Electronics Engineering, Adana \\ ${ }^{2}$ Adana Alparslan Türkeş Science and Technology University, Department of Electrical and \\ Electronics Engineering, Adana
}

Geliş tarihi: $30.07 .2021 \quad$ Kabul tarihi: 10.12 .2021

Attf şekli/ How to cite: CUMA, M.U., SAVRUN, M.M., (2021). Performance Benchmarking of ActiveFront-End Rectifier Topologies Used in High-Power, High-Voltage Onboard EV Chargers. Çukurova Üniversitesi, Mühendislik Fakültesi Dergisi, 36(4), 1041-1050.

\begin{abstract}
High power onboard battery chargers employed in electric vehicles (EVs) and plug-in hybrid EVs (PHEVs) fed from three-phase mains typically consist of a two-stage structure as AC-DC and DC-DC stages. The AC-DC stage is also known as the active front end (AFE). While the AFE rectifies the mains voltage, maintains the power factor, and provides a constant DC-link voltage to the DC-DC converter, the DC-DC converter stage regulates the charging current considering the charging algorithms in order to extend the battery service life. This study focuses on the selection of cost/performance effective AFE topology that can be used in high power onboard chargers. Four different suitable AC-DC topologies are investigated: (i) 3-phase 2-level rectifier, (ii) 3-phase, 3-level neutral-point-clamped (NPC) rectifier, (iii) 3-phase, 3-level T-type rectifier, and (iv) Vienna rectifier. In this study, the aforementioned AFE topologies have been simulated on the PLECS/SpeedFit environment and compared in terms of efficiency, losses, temperature, the number of switching elements, cost and cost/efficiency metrics. The performance results of the aforementioned topologies have been evaluated under different operating frequencies. The results reveal that the most suitable topology alternatives for the front-end AC-DC converter are 3-phase 2-level PWM rectifier and Vienna rectifier. Although the 3-phase 2-level PWM rectifier is superior with its $12 \%$ cost advantage, fewer components, and ease of control advantages, it lags a little behind the Vienna rectifier in terms of total harmonic distortion.
\end{abstract}

Keywords: Onboard battery charger, Electric vehicle, Plug-in, Active front end, rectifier

\footnotetext{
"Sorumlu yazar (Corresponding author): Mehmet Uğraş CUMA, mcuma@cu.edu.tr
} 


\section{Yüksek Güçlü, Yüksek Gerilimli Yerleşik EV Şarj Cihazlarında Kullanılan Active-Front-End Doğrultucu Topolojilerinin Performans Kıyaslaması}

\section{$\ddot{\mathbf{O} z}$}

Üç fazlı şebekeden beslenen Elektrikli araçlarda (EA'lar) ve plug-in hibrit EV'lerde (PHEA'lar) kullanılan yüksek güçlü yerleşik batarya şarj cihazları genellikle AA-DA ve DA-DA olarak iki aşamalı bir yapıdan oluşur. AA-DA aşaması, active-front-end (AFE) olarak da bilinir. AFE, şebeke gerilimini doğrultup, güç faktörünü düzenleyip ve DA-DA dönüştürücüye sabit bir DC-bara gerilimi sağlarken, DA-DA dönüştürücü aşaması, batarya ömrünü uzatmak için şarj algoritmalarını dikkate alarak şarj akımını regüle eder. Bu çalışma, yüksek güçlü yerleşik şarj cihazlarında kullanılabilecek maliyet/performans açısından etkin AFE topolojisinin seçimine odaklanmaktadır. Uygun olan dört farklı AA-DA topolojisi incelenmiştir: (i) 3-fazlı 2-seviyeli doğrultucu, (ii) 3-fazlı, 3-seviyeli nötr nokta-bağlantılı (NPC) doğrultucu, (iii) 3-fazlı, 3-seviye T tipi doğrultucu ve (iv) Viyana doğrultucu. Bu çalışmada, yukarıda bahsedilen AFE topolojileri PLECS/SpeedFit ortamında simüle edilmiş ve verimlilik, kayıplar, sıcaklık, anahtarlama elemanları sayısı, maliyet ve maliyet/verimlilik ölçütleri açısından karşılaştırılmıştır. Söz konusu topolojilerin performans sonuçları farklı çalışma frekansları altında değerlendirilmiştir. Sonuçlar, front-end AA-DA dönüştürücü için en uygun topoloji alternatiflerinin 3 fazlı 2 seviyeli PWM doğrultucu ve Viyana doğrultucu olduğunu ortaya koymaktadır. 3 fazlı 2 seviyeli PWM doğrultucu \%12 maliyet avantajı, daha az bileşen ve kontrol kolaylı̆̆ı avantajları ile üstün olmasına rağmen, toplam harmonik bozulma açısından Viyana doğrultucunun biraz gerisinde kalmaktadır.

Anahtar Kelimeler: Araçüstü batarya şarj cihazı, Elektrikli araç, Fişli, Active-front-end, Doğrultucu

\section{INTRODUCTION}

Transportation has a great portion of primary energy consumption across the world [1]. In view of the fact that a large part of the energy for the transportation sector has been supplied by fossil fuels, spreading the utilization of electric vehicles (EVs) and plug-in hybrid EVs (PHEVs) is a promising phenomenon in order to decrease the usage of fossil fuels and greenhouse gas emission. One of the essential components of the EVs are the batteries and hence the onboard battery chargers (OBCs) that are employed to charge the batteries from ac grid and to provide galvanic isolation between EVs and grid. Typically, OBCs are categorized into two as single-stage and two-stage power conversion [2]. While the single-stage OBCs have large low-frequency ripples in the output current, two-stage OBCs reject inherent low-frequency ripple in the output current [3, 4]. As illustrated in Figure 1, two-stage OBCs are composed of AC-DC, DC-DC converter stages and a dc-link capacitor. The three-phase AC-DC converter stage, which is widely used in various industrial applications and named active front end, rectifies the mains voltage, maintains the power factor and provides a controllable DC-link voltage to the DC-DC converter [5].

Recently, various studies have been carried out in order to improve the performance of AFE in the aspect of dc-link voltage control, dc-link voltage ripple, total harmonic distortion (THD) [6], power factor and the size of dc-link capacitor [7] in OBCs. Traditional rectifiers that are composed of a three-phase diode bridge (passive rectifiers) and phase-controlled thyristor structures have some drawbacks of dc-link voltage based on grid instantaneous state, low power factor, and harmonic line currents. Thus, pulse-widthmodulated (PWM) rectifier structures are frequently employed to improve the input/output performance of the AFE in modern EVs [8]. PWM based AFE rectifiers are categorized into two as two-level and multilevel. While the two-level topologies excel with reduced switching component and reduced computational load/complexity, the multilevel topologies such as 
Vienna rectifier [9, 10], Swiss rectifier [11,12], Ttype rectifier [13], NPC rectifier [14], and matrix converter [15] offer reduced size, switching frequency and stress [16]. Some authors $[15,17,18]$ have been classified, compared, and discussed the existing AFE rectifiers to explain their basic functions and control methodologies.

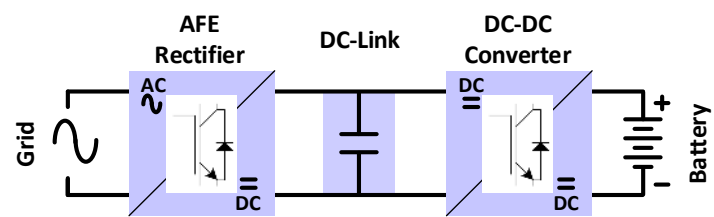

Figure 1. Circuit configuration of two-stage OBCs

In the meanwhile, the size and cost in addition to the performance of AFE topologies are the other essential aspects to make them available for EVs. Although several studies have addressed the performance comparison of AFE topologies in the literature, studies evaluating AFE topologies in terms of size and cost as well as performance are lacking.

In this paper, comprehensive researches about four different suitable AFE topologies as; (i) 3-phase 2level rectifier, (ii) 3-phase, 3-level neutral-pointclamped (NPC) rectifier, (iii) 3-phase, 3-level Ttype rectifier, and (iv) Vienna rectifier used in studies with power over $20 \mathrm{~kW}$ have been presented. The study focuses on the terms of efficiency, losses, temperature, the number of switching elements, cost and cost/performance metrics of AFEs. The switching/conduction/total losses, junction temperature, and efficiency evaluations of the related topologies have been carried out under different switching frequencies on the PLECS/SpeedFit environment. In addition, the comparison of the topologies regarding the number of switching elements, cost, and cost/performance have been performed.

The rest of the paper is organized as follows: Section II introduces the specifications, power circuits, and the performance evaluations of the aforementioned AFE topologies. Section III presents the benchmarking of the related AFE topologies in terms on cost metrics. Section IV puts forward conclusions with relevant discussion.

\section{AFE RECTIFIER TOPOLOGIES AND PERFORMANCE EVALUATIONS}

This section of the paper describes the topologies and design specifications of AFEs and evaluates the performance waveforms, switching/ conduction/total losses, junction temperatures, and efficiency values of them. AFE topologies have been determined considering the most commonly used Level-2 OBCs in EVs [19]. The related topologies have been simulated considering the design specifications given in Table 1 which corresponds to Level-2 charger features. SiC MOSFETs of a certain manufacturer (CREE) have been used in order to make a correct comparison between topologies. Simulations have been performed under different switching frequencies of $10 \mathrm{kHz}$ and $20 \mathrm{kHz}$ to investigate the effects of it on efficiency, temperature and waveforms. The thermal coefficients and additional heat source on heatsink have been determined as high to examine the worst-case scenario.

Table 1. Design specifications of AFEs

\begin{tabular}{|l|l|}
\hline Parameters & Values \\
\hline Input voltage & $400 \mathrm{~V} \mathrm{AC}$ \\
\hline Nominal output voltage & $800 \mathrm{~V} \mathrm{DC}$ \\
\hline Nominal output power & $22 \mathrm{~kW}$ \\
\hline Junction-case thermal resistance & $0.45 \mathrm{C} / \mathrm{W}$ \\
\hline Case-cooler thermal resistance & $0.2 \mathrm{C} / \mathrm{W}$ \\
\hline Ambient temperature & $60{ }^{\circ} \mathrm{C}$ \\
\hline $\begin{array}{l}\text { Additional heat source on } \\
\text { heatsink }\end{array}$ & $300 \mathrm{~W}$ \\
\hline
\end{tabular}

\subsection{3-Phase 2-Level Rectifier}

The circuit configuration of the 3-phase 2-level rectifier which is one of the most commonly used rectifier type is shown in Figure 2. It consists of input inductances of $0.75 \mathrm{mH}$ and six C3M0032120D MOSFETs. A three-phase fullbridge converter is able to reach high power levels 
and makes it possible to reduce the charging times of EVs. The body diodes of the MOSFETs provide a bidirectional current path. Thus, the related AFE topology also allows power transfer from the vehicle to the grid that is the concept called V2G. In addition, the topology is able to reconfigure by bypassing one leg in order to operate as an $\mathrm{H}$ bridge inverter to supply other loads [20]. The performance results of the rectifier performed under switching frequencies of $10 \mathrm{kHz}$ and $20 \mathrm{kHz}$ are illustrated in Figure 3(a) and Figure 3(b), respectively.
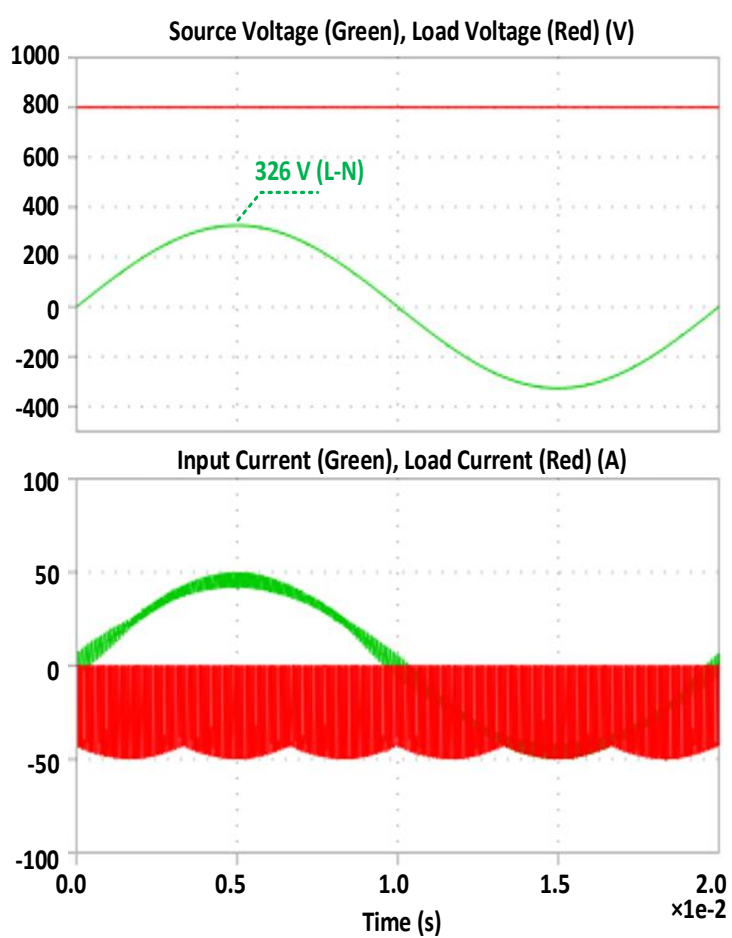

(a)

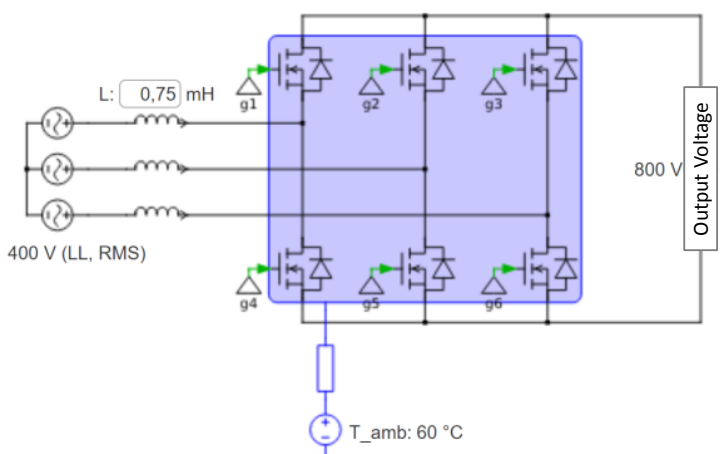

Figure 2. Circuit configuration of 3-phase 2-level rectifier
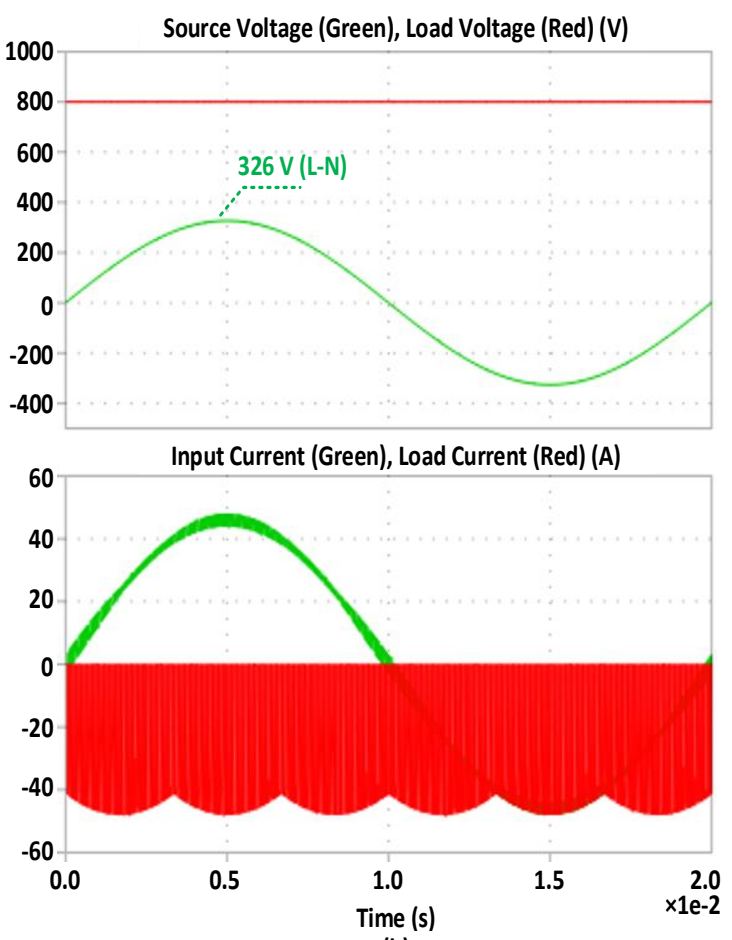

(b)

Figure 3. Performance waveforms of 3-phase 2-level rectifier under (a) $10 \mathrm{kHz}$ (b) $20 \mathrm{kHz}$ switching frequencies

As shown in Figure 3, the grid voltage is rectified and regulated to constant $800 \mathrm{~V}$ with sinusoidal input current. It can be observed that the high frequency current ripples and harmonic distortion in the input current are high in comparison with multilevel topologies. The input current/voltage waveforms reveal the power factor is approximately 1 .

\subsection{3-Phase, 3-Level NPC Rectifier}

The circuit configuration of the 3-phase 3-level NPC rectifier which is adopted to reduce the 
voltage stress of MOSFETs, the size of the dc-link capacitor, and current harmonics is shown in Figure 4. It consists of input inductances of 0.75 $\mathrm{mH}$ and twelve switches with neutral point diodes. The MOSFETs and diodes are C3M0045065D, C3D20065D, respectively. Although it has some advantages in capacitor size, voltage stress, and harmonics, it has more switching elements and high control complexity [21]. The performance results of the simulations performed under switching frequencies of $10 \mathrm{kHz}$ and $20 \mathrm{kHz}$ are illustrated in Figure 5(a) and Figure 5(b), respectively.
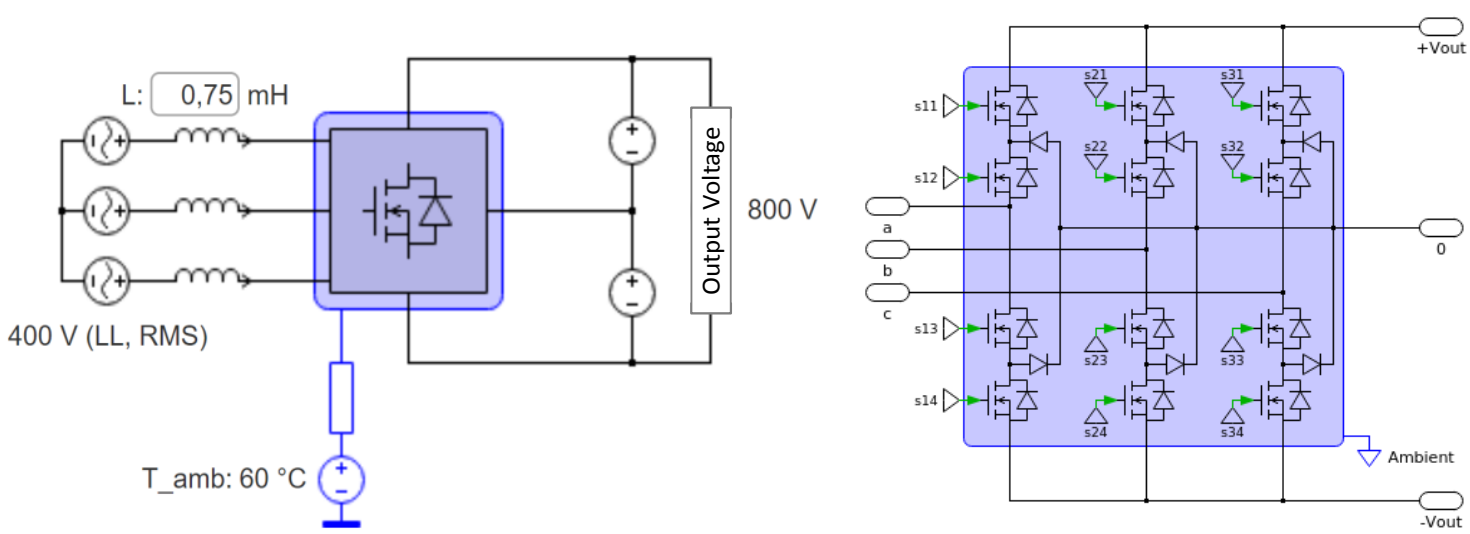

Figure 4. Circuit configuration of 3-phase 3-level NPC rectifier

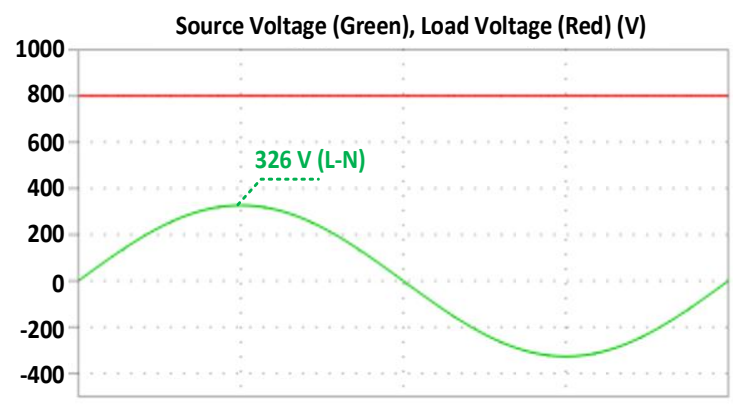

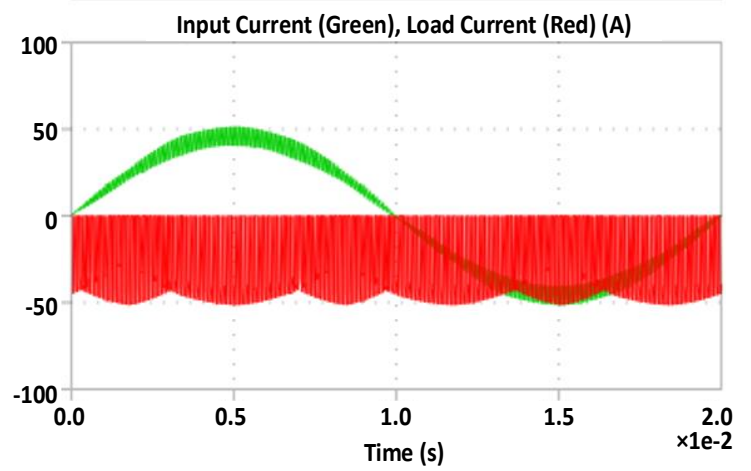

(a)
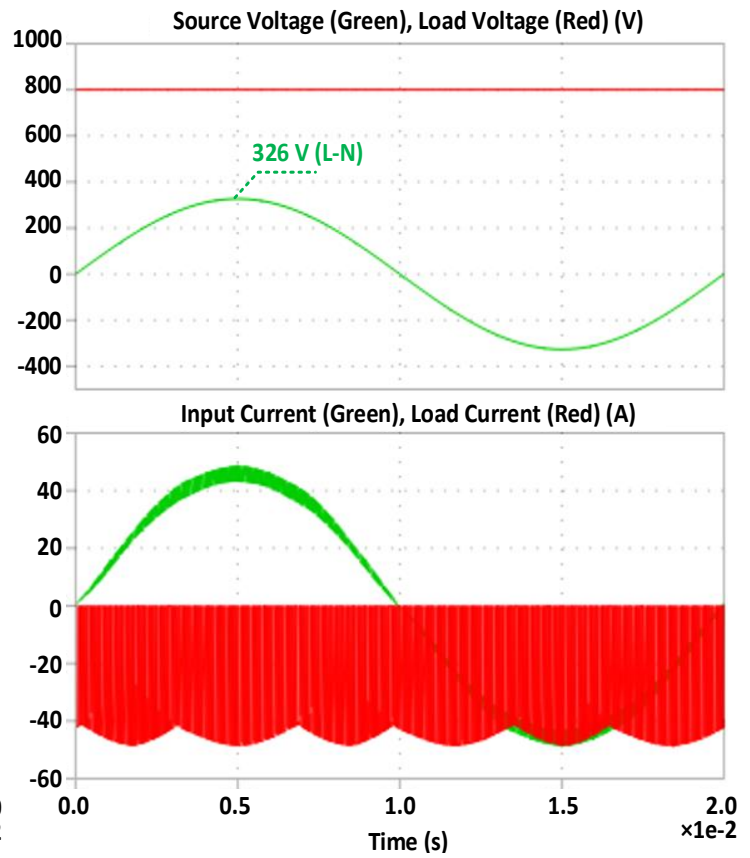

(b)

Figure 5. Performance waveforms of 3 phase 3 -level NPC rectifier under (a) $10 \mathrm{kHz}$ (b) $20 \mathrm{kHz}$ switching frequencies 
As shown in Figure 5, the grid voltage is rectified and regulated to constant $800 \mathrm{~V}$ and the balanced and sinusoidal line currents are drawn from the ac grid. It can be observed that the three-level topology eliminates the high frequency current ripples and harmonic distortion drawbacks of twolevel topology. The power factor is controlled around unity as can be seen from the input current/voltage waveforms.

\subsection{3-Phase, 3-Level T-Type Rectifier}

The circuit configuration of the 3-phase 3-level Ttype rectifier, which has such advantages; low conduction/switching losses, simple operation principle and low switches stress in comparison with 3-phase 3-level NPC rectifier topology is shown in Figure 6 [22]. It consists of input inductances of $0.75 \mathrm{mH}$, six C3M0032120D MOSFETs, and six C3M0045065D side MOSFETs. The performance results of the simulations performed under switching frequencies of $10 \mathrm{kHz}$ and $20 \mathrm{kHz}$ are illustrated in Figure 7(a) and Figure 7(b), respectively.
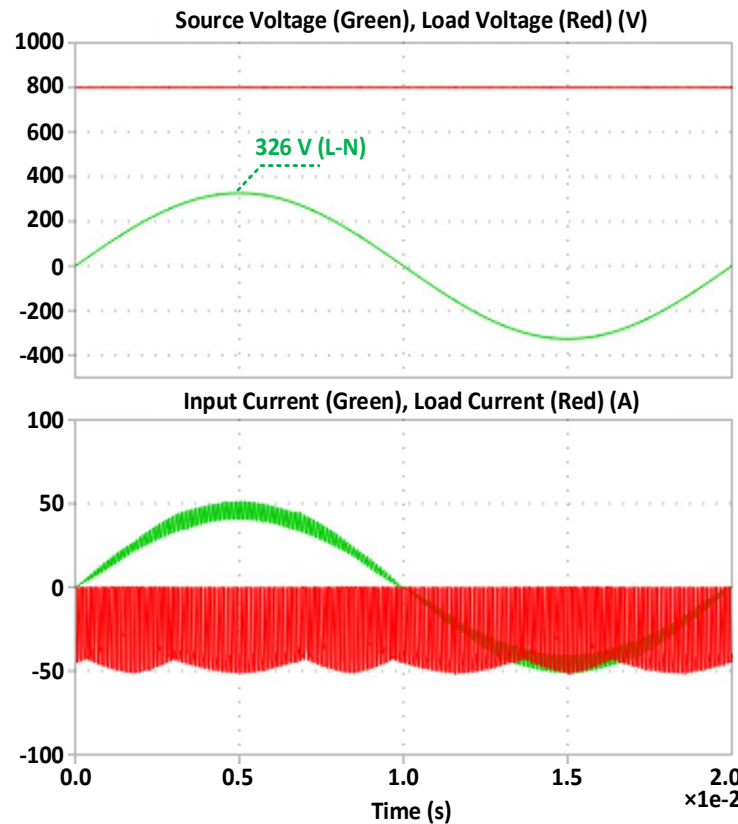

(a)

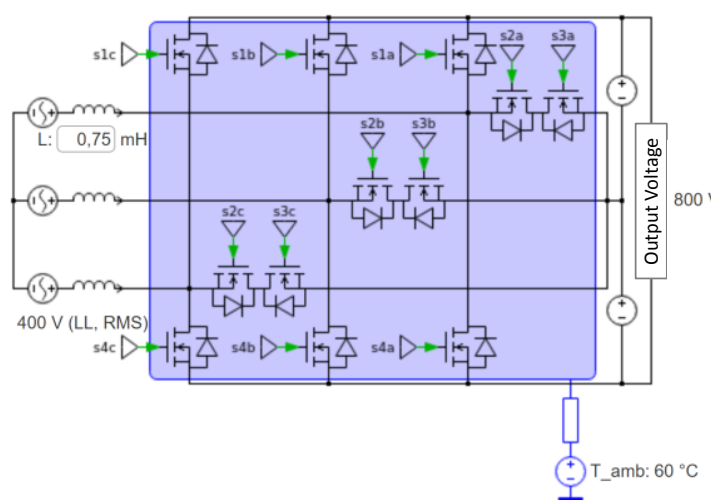

Figure 6. Circuit configuration of 3-phase 3-level T-type rectifier

As shown in Figure 7, the grid voltage is rectified and regulated to constant $800 \mathrm{~V}$ and the balanced and sinusoidal line currents are drawn from the ac grid. It can be observed that the total harmonic distortion (THD) of input current in phases is about acceptable limits. The power factor is controlled around unity as can be seen from the input current/voltage waveforms.
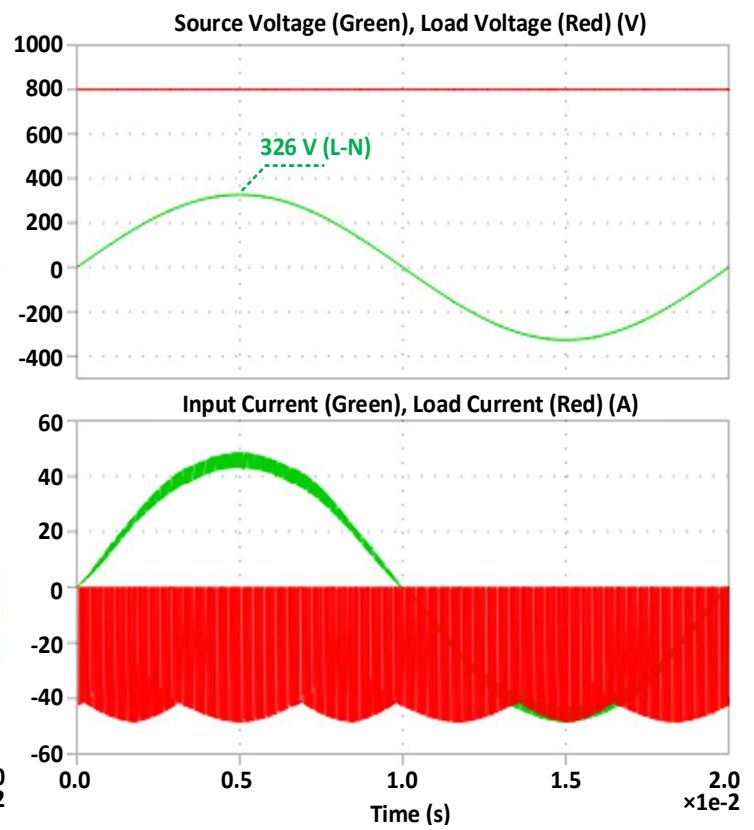

(b)

Figure 7. Performance waveforms of 3 phase 3-level T-type rectifier under (a) $10 \mathrm{kHz}$ (b) $20 \mathrm{kHz}$ switching frequencies 


\subsection{Vienna Rectifier}

The circuit configuration of the Vienna rectifier, which is the most frequently used rectifier type in OBCs because of reduced switch and control complexity, is shown in Figure 8. It consists of input inductances of $0.75 \mathrm{mH}$, six C4D40120D diodes, and six C3M0045065D MOSFETs. The converter allows unidirectional power flow because of diodes in the legs. Thus, it is usually used in applications that do not require regeneration or controllable input reactive power [23]. The performance results of the simulations performed under switching frequencies of $10 \mathrm{kHz}$ and $20 \mathrm{kHz}$ are illustrated in Figure 9(a) and Figure 9(b), respectively.

As shown in Figure 9, the grid voltage is rectified and regulated to constant $800 \mathrm{~V}$ and the balanced and sinusoidal line currents are drawn from the ac grid. It can be observed that the total harmonic
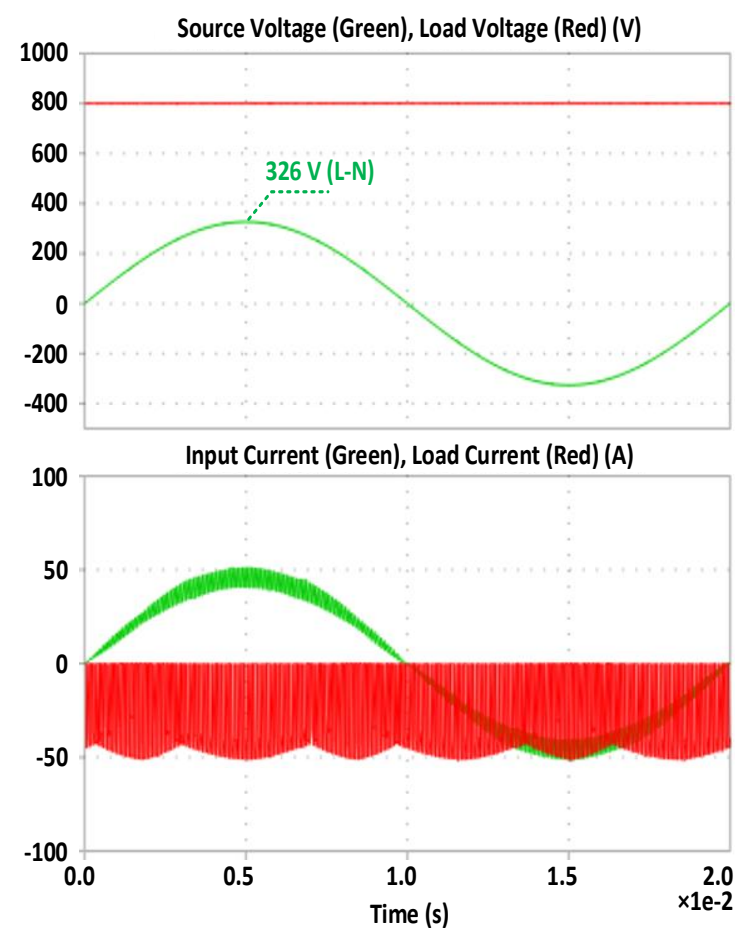

(a) distortion (THD) of input current in phases is about acceptable limits. The power factor is controlled around unity as can be seen from the input current/voltage waveforms.

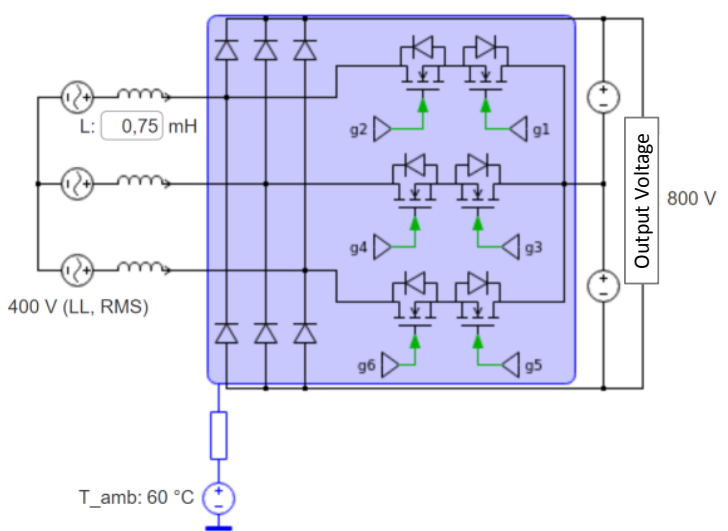

Figure 8. Circuit configuration of Vienna rectifier
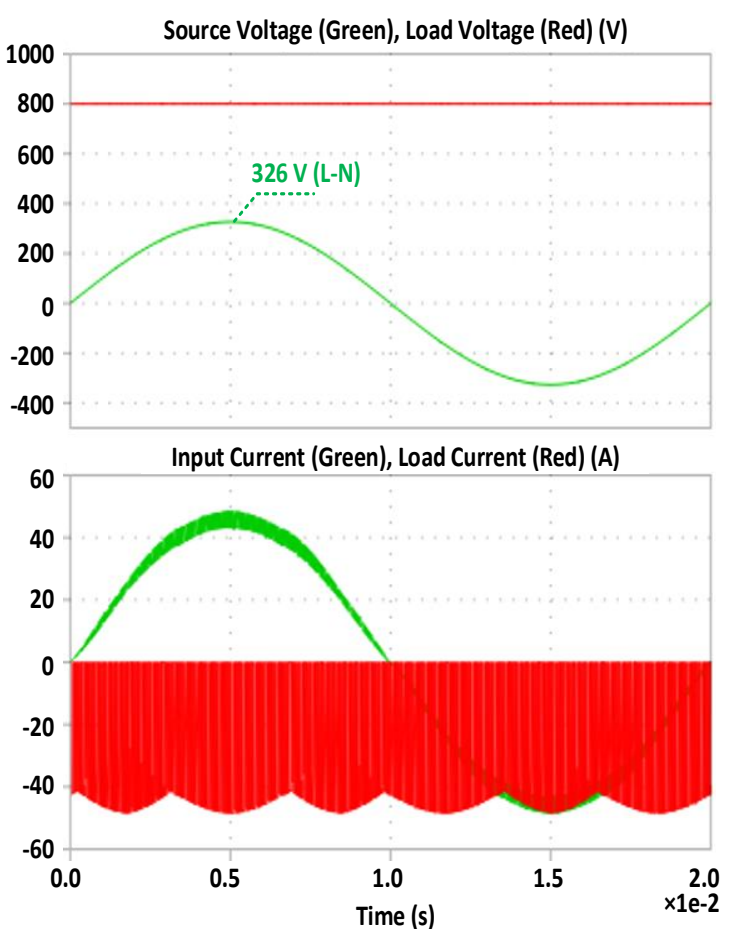

(b)

Figure 9. Performance waveforms of Vienna rectifier under (a) $10 \mathrm{kHz}$ (b) $20 \mathrm{kHz}$ switching frequencies 


\section{BENCHMARKIG OF TOPOLOGIES}

In this section, the performance results and the cost metrics of the aforementioned AFEs are presented.

Table 2 presents the switching/conduction/total losses, junction temperatures and efficiency values according to the number of parallel MOSFETs under switching frequencies of $10 \mathrm{kHz}$ and $20 \mathrm{kHz}$ for all AFE topologies. As can be seen from the table, the junction temperatures are within the acceptable limits, the switching/conduction/total losses are low and the efficiency is very high. The effect of using parallel MOSFETs/Diodes are also examined and the results highlight that junction temperature and the losses drastically decreases, and efficiency improves. The performance results reveal that all rectifiers have approximately the same efficiency and junction temperature values. Therefore, it is essential to consider cost and cost/performance metrics as well as performance results in converter benchmarking.
Table 3 presents cost, efficiency, and cost/efficiency metrics using a $2 \mathrm{ohm}$ gate resistor and $20 \mathrm{kHz}$ switching frequency. In order to compare the topologies, the cost/efficiency index has been defined and the lowest index value is assumed as the most suitable topology. The calculations have been performed by considering not only the number of MOSFETs and diodes, but also the costs of the driver and the isolated power supplies required for them, and the PCB unit costs that will arise with the increase in the number of switches and drivers. As can be seen from the table, the most suitable topology alternatives are 3phase 2-level PWM rectifier and Vienna rectifier. The 3-phase 2-level PWM rectifier excels with its $12 \%$ cost advantage, fewer components, and ease of control advantages. Although the 3-Phase 2Level rectifier has a disadvantage in terms of total harmonic distortion, it is considered that this disadvantage can be eliminated thanks to the EMI filters to be designed at the input.

Table 2. Performance results of 3-phase 2-level rectifier under $10 \mathrm{kHz}$ and $20 \mathrm{kHz}$ switching frequencies

\begin{tabular}{|c|c|c|c|c|c|c|c|c|c|}
\hline Topologies & & $\begin{array}{l}\mathbf{R g} \\
(\mathbf{\Omega})\end{array}$ & $\begin{array}{c}\text { SwFrq } \\
(\mathrm{kHz})\end{array}$ & $\begin{array}{c}\text { Parallel } \\
\text { MOSFETs/Diodes }\end{array}$ & $\begin{array}{l}\text { Switching } \\
\text { Loss (W) }\end{array}$ & $\begin{array}{c}\text { Conduction } \\
\text { Loss (W) }\end{array}$ & $\begin{array}{l}\text { Total Loss } \\
\text { (W) }\end{array}$ & $\begin{array}{c}\text { Junction } \\
\text { Temperature } \\
\left({ }^{\circ} \mathrm{C}\right) \\
\end{array}$ & Eff. $(\%)$ \\
\hline \multirow{4}{*}{ 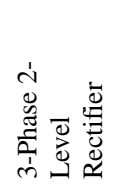 } & MOSFET & \multirow{2}{*}{2} & \multirow{2}{*}{10} & 1 & 56.03 & 133.27 & 189.30 & 106.4 & 99.16 \\
\hline & MOSFET & & & 2 & 42.07 & 64.99 & 107.06 & 83.4 & 99.52 \\
\hline & MOSFET & \multirow{2}{*}{2} & \multirow{2}{*}{20} & 1 & 118.68 & 137.81 & 256.48 & 117.3 & 98.86 \\
\hline & MOSFET & & & 2 & 88.37 & 67.35 & 155.72 & 89.3 & 99.31 \\
\hline \multirow{4}{*}{ 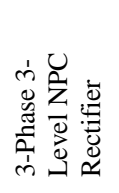 } & MOSFET & \multirow{2}{*}{2} & \multirow{2}{*}{10} & 1 & 16.21 & 290.79 & \multirow{2}{*}{331.49} & 127.7 & \multirow{2}{*}{98.53} \\
\hline & DIODE & & & 2 & 0 & 24.49 & & 91.5 & \\
\hline & MOSFET & \multirow{2}{*}{2} & \multirow{2}{*}{20} & 1 & 34.06 & 293.44 & \multirow{2}{*}{351.81} & 128.8 & \multirow{2}{*}{98.44} \\
\hline & DIODE & & & 2 & 0 & 24.31 & & 92.1 & \\
\hline \multirow{4}{*}{ 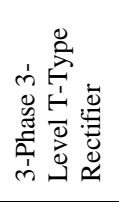 } & MOSFET & \multirow{2}{*}{2} & \multirow{2}{*}{10} & 1 & 0 & 89.30 & \multirow{2}{*}{208.37} & 98.9 & \multirow{2}{*}{99.05} \\
\hline & S. MOSFET & & & 1 & 15.93 & 109.14 & & 109.4 & \\
\hline & MOSFET & 2 & 20 & 1 & 0.01 & 90.95 & 23387 & 99.8 & 98.96 \\
\hline & S. MOSFET & & & 1 & 33.44 & 109.47 & & 115.5 & \\
\hline \multirow{4}{*}{ 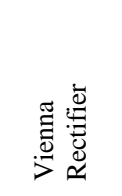 } & MOSFET & \multirow{2}{*}{2} & \multirow{2}{*}{10} & 1 & 14.57 & 109.22 & \multirow{2}{*}{221.34} & 109.4 & \multirow{2}{*}{99.02} \\
\hline & DIODE & & & 1 & 0 & 97.55 & & 93.2 & \\
\hline & MOSFET & \multirow{2}{*}{2} & \multirow{2}{*}{20} & 1 & 30.30 & 109.47 & \multirow{2}{*}{237.16} & 114.7 & \multirow{2}{*}{98.95} \\
\hline & DIODE & & & 1 & 0 & 97.39 & & 93.8 & \\
\hline
\end{tabular}


Table 3. Benchmarking of AFE topologies

\begin{tabular}{|c|c|c|c|c|c|c|c|c|c|c|c|c|}
\hline \multirow[t]{2}{*}{ Topologies } & \multicolumn{2}{|c|}{ MOSFETs } & \multicolumn{2}{|c|}{$\begin{array}{c}\text { Side } \\
\text { MOSFETs }\end{array}$} & \multicolumn{2}{|c|}{ Diodes } & \multicolumn{2}{|c|}{$\begin{array}{c}\text { Drivers } \\
\text { Auxiliary } \\
\text { Components } \\
\end{array}$} & \multirow{2}{*}{\begin{tabular}{|c|} 
PCB \\
Unit \\
Cost \\
Cost \\
(USD)
\end{tabular}} & \multirow{2}{*}{$\begin{array}{l}\text { Total } \\
\text { Costs } \\
\text { (USD) }\end{array}$} & \multirow{2}{*}{$\begin{array}{l}\text { Eff. } \\
(\%)\end{array}$} & \multirow{2}{*}{$\begin{array}{l}\text { Cost/ } \\
\text { Eff. }\end{array}$} \\
\hline & Pcs. & $\begin{array}{c}\text { Cost } \\
\text { (USD) }\end{array}$ & Pcs. & $\begin{array}{c}\text { Cost } \\
\text { (USD) }\end{array}$ & Pes. & $\begin{array}{c}\text { Cost } \\
\text { (USD) }\end{array}$ & Pcs. & $\begin{array}{c}\text { Cost } \\
\text { (USD) }\end{array}$ & & & & \\
\hline $\begin{array}{l}\text { 3-Phase 2- } \\
\text { Level } \\
\text { Rectifier } \\
\end{array}$ & 6 & 33.89 & - & - & - & - & 6 & 20 & 20 & 343.34 & 98.86 & 3.473 \\
\hline $\begin{array}{l}\text { 3-Phase 3- } \\
\text { Level NPC } \\
\text { Rectifier }\end{array}$ & 12 & 10.55 & - & - & 12 & 4.18 & 12 & 20 & 40 & 456.76 & 98.44 & 4.639 \\
\hline $\begin{array}{l}\text { 3-Phase 3- } \\
\text { Level T- } \\
\text { Type } \\
\text { Rectifier }\end{array}$ & 6 & 33.89 & 6 & 10.55 & - & - & 12 & 20 & 40 & 546.64 & 98.96 & 5.524 \\
\hline $\begin{array}{l}\text { Vienna } \\
\text { Rectifier }\end{array}$ & 6 & 10.55 & - & - & 6 & 28.75 & 6 & 20 & 30 & 385.8 & 98.95 & 3.898 \\
\hline
\end{tabular}

(Cost References: www.digikey.com, Date: 10.07.2021)

\section{CONCLUSIONS}

This paper presents the benchmarking of AFE rectifier topologies that are commonly employed in commercially available OBCs in the aspects of losses, efficiency, cost, and cost/efficiency metrics. The main objectives of AFE rectifiers are; (i) high efficiency, (ii) high power factor, and (ii) minimum input current distortion. Four different suitable AC-DC topologies in literature and among commercially available products are (i) 3-phase 2level rectifier, (ii) 3-phase, 3-level neutral-pointclamped (NPC) rectifier, (iii) 3-phase, 3-level Ttype rectifier, and (iv) Vienna rectifier. While the paper summarizes the aforementioned topologies and their advantages, it also presents performance waveforms captured on the PLECS/SpeedFit environment. In addition, the most effective topology has been determined by considering not only performance results but also the cost/efficiency index. The cost/efficiency index validates the effectiveness of the 3-Phase 2-Level and Vienna rectifiers in comparison with latter topologies. Although the two topologies stand out considering the cost/efficiency index, the 3-Phase 2-Level rectifier has a $12 \%$ cost advantage over the Vienna rectifier. The drawback of input current distortion of the 3-Phase 2-Level rectifier in comparison with the Vienna rectifier can be eliminated using an EMI filter.

\section{REFERENCES}

1. Umar, M., Ji, X., Kirikkaleli, D., Alola, A.A., 2021. The Imperativeness of Environmental Quality in the United States Transportation Sector Amidst Biomass-fossil Energy Consumption and Growth. Journal of Cleaner Production, 285, 1-15.

2. Qian, Q., Sun, W., Zhang, T., Lu, S., 2017. A Voltage-fed Single-stage PFC Full-bridge Converter with Asymmetric Phase-shifted Control for Battery Chargers. Journal of Power Electronics, 17, 31-40.

3. Musavi, F., Edington, M., Eberle, W., Dunford, W.G., 2012. Evaluation and Efficiency Comparison of Front end AC-DC Plug-in Hybrid Charger Topologies. IEEE Transactions on Smart Grid, 3(1), 413-421.

4. Nguyen, H.V., To, D., Lee, D., 2018. Onboard Battery Chargers for Plug-in Electric Vehicles with Dual Functional Circuit for Low-voltage Battery Charging and Active Power Decoupling. IEEE Access, 6, 70212-70222.

5. Bayhan, S., Komurcugil, H., 2020. SlidingMode Control Strategy for Three-Phase ThreeLevel T-Type Rectifiers with DC Capacitor Voltage Balancing. IEEE Access, 8, 6455564564.

6. Mallik, A., Khaligh, A., 2017. Control of a Three-Phase Boost PFC Converter Using a Single DC-Link Voltage Sensor. IEEE 
Transactions on Power Electronics, 32(8), 6481-6492.

7. Lee, Y., Khaligh, A., Emadi, A., 2009. Advanced Integrated Bidirectional AC/DC and DC/DC Converter for Plug-in Hybrid Electric Vehicles. IEEE Transactions on Vehicular Technology, 58(8), 3970-3980.

8. Komurcugil, H., Kukrer, O., 1998. Lyapunovbased Control for Three-phase PWM AC/DC Voltage-source Converters. IEEE Transactions on Power Electronics, 13(5), 801-813.

9. Kalpana, S.P.P,R., Singh, B., Bhuvaneswari, G., 2018. Design and Implementation of Sensorless Voltage Control of Front-end Rectifier for Power Quality Improvement in Telecom System. IEEE Transactions on Industry Applications, 54(3), 2438-2448.

10. Liu, B., Ren, R., Jones, E.A., Wang, F., Costinett, D., Zhang, Z., 2018. A Modulation Compensation Scheme to Reduce Input Current Distortion in GaN-based High Switching Frequency Three-phase Three-level Vienna-type Rectifiers. IEEE Transactions on Power Electronics, 33(1), 283-298.

11.Zhang, B., Xie, S., Li, Z., Zhao, P., Xu, J., 2021. An Optimized Single-Stage Isolated Swiss-Type AC/DC Converter Based on Single Full-bridge with Midpoint-clamper. IEEE Transactions on Power Electronics, 36(10), 11288-11297.

12. Schrittwieser, L., Leibl, M., Haider, M., Thöny, F., Kolar, J.W., Soeiro, T.B., 2017. 99.3\% Efficient Three-phase Buck-type All-SiC SWISS Rectifier for DC Distribution Systems. in 2017 IEEE Applied Power Electronics Conference and Exposition (APEC), 2173-2178.

13. Stoermer, F., Eckel, H., 2018. SiC-hybrid Three Level T-type Rectifier, in PCIM Europe 2018; International Exhibition and Conference for Power Electronics. Intelligent Motion. Renewable Energy and Energy Management, 1-6.

14. Rodriguez, J., Bernet, S., Steimer, P.K., Lizama, I.E., 2010. A Survey on Neutral-point- clamped Inverters. IEEE Transactions on Industrial Electronics, 57(7), 2219-2230.

15. Kolar, J.W., Friedli, T., 2013. The Essence of Three-Phase PFC Rectifier Systems-part I. IEEE Transactions on Power Electronics, 28(1), 176-198.

16. Yilmaz, M., Krein, P.T., 2013. Review of Battery Charger Topologies, Charging Power Levels, and Infrastructure for Plug-in Electric and Hybrid Vehicles. IEEE Transactions on Power Electronics, 28(5), 2151-2169.

17. Friedli, T., Hartmann, M., Kolar, J..W., 2014. The Essence of Three-Phase PFC Rectifier Systems-part II. IEEE Transactions on Power Electronics, 29(2), 543-560.

18. Aretxabaleta, I., Alegría, I. M. D., Andreu, J., Kortabarria, I., Robles, E., 2021. High-voltage Stations for Electric Vehicle Fast-charging: Trends, Standards, Charging Modes and Comparison of Unity Power-Factor Rectifiers. IEEE Access, 9, 102177-102194.

19. Shi, C., Tang, Y., Khaligh, A., 2017. A Singlephase Integrated Onboard Battery Charger Using Propulsion System for Plug-in Electric Vehicles. IEEE Transactions on Vehicular Technology, 66(12), 10899-10910.

20. Yuan, J., Dorn-Gomba, L., Callegaro, A. D., Reimers, J., Emadi, A., 2021. A Review of Bidirectional On-board Chargers for Electric Vehicles. IEEE Access, 9, 51501-51518.

21. Bor-Ren, L., Yung-Chuan, L., Tsung-Yu, Y., 2004. Implementation of a Three-phase Highpower-factor Rectifier with NPC Topology. IEEE Transactions on Aerospace and Electronic Systems, 40(1), 180-189.

22. Chen, J., Zhang, C., Chen, A., Xing, X., Gao, F., 2019. A Carrier-Based Fault-Tolerant Control Strategy for T-type Rectifier with Neutral-point Voltage Oscillations Suppression. IEEE Transactions on Power Electronics, 34(11), 10988-11001.

23. Mukherjee, D., Kastha, D., 2019. Voltage Sensorless Control of VIENNA Rectifier in the Input Current Oriented Reference Frame. IEEE Transactions on Power Electronics, 34(8), 8079-8091. 